\title{
TOURISM AND HERITAGE: A DIALOGUE OF DEAF - STILL NOT SOLVED... ${ }^{1}$
}

\author{
Anya Diekmann \\ Université Libre de Bruxelles, \\ Bruxelles, Belgium
}

Correspondence:

Anya Diekmann

e-mail:

anya.diekmann@ulb.ac.be

\section{Abstract:}

Heritage and tourism are very closely connected, because on the one hand heritage is one of the major assets for cultural tourism and on the other hand heritage sites can gain from tourism for the site preservation. Yet, the relationship between the two is very conflictual leading to overuse and deterioration of heritage sites due to common management policies and synergies between the different stakeholders. The paper, summarising a keynote given at the SITCON 2018, looks into the relationship between heritage and tourism and highlights these at hand of a world heritage site in Brussels (Belgium), the Grand Place.

\section{Keywords:}

heritage, tourism, site management Brussels, Grand Place

\section{INTRODUCTION}

First of all, I wish to thank you for the invitation to come and talk about my research on the heritage and tourism relationship.

In 2000, I started writing my $\mathrm{PhD}$ on the relationship between heritage and tourism, stating that the relationship wasn't at its best, if not often non-existing with numerous consequences for heritage preservation as well as for tourism in heritage sites. Between 2008 and 2010 we participated in a European project MECOAN - Preserving Places - Managing mass tourism, urban conservation and quality of life in historic centres ${ }^{2}$ where together with academic partners form several countries, we compared heritage and tourism management in Rome, Madrid and Brussels. The research was one of the first that provided empirical evidence for the conflictual relationship tackling tourism flows in historic city centres and the perception of the various stakeholders. The research confirmed the difference of perception for the heritage and tourism sides and the lack of willingness to cooperate. Reasons were mainly that neither side feels competent in the other field (Diekmann \& Gillot, 2010).

In 2018, we must acknowledge that this dichotomy between heritage and tourism is unfortunately still prevalent. In a rather vicious way and due to the absence of dialogue, the prejudgements of both sides

1 This text refers to the Anya Diekmann's keynote speech - Author's notes from SITCON 2018 Conference lecture

2 See special Issue, Revista di Scienze del Turismo Vol 1, No 2 (2010) http://www. ledonline.it/index.php/Rivista-Scienze-Turismo/issue/view/37/showToc 
have actually materialised in a way that today even more heritage sites are threatened by an increasing and uncontrolled number of tourists, termed since recently as 'overtourism's. This is often due to a lack of appropriate management resulting in the overuse of heritage attractions and uneven spatial distribution of tourists leading to overcrowding where physical obstructions block the natural flow or narrow passages causing the flow to slow down (UNWTO, 2004). In the long run congestion and overtourism threatens both, the physical and cultural integrity of the site.

Management plans can be a tool for a balanced approach. After sharing some thoughts on the relationship, the paper analyses the example of a world heritage site, the Grand Place in Brussels.

\section{THE HERITAGE TOURISM RELATIONSHIP}

Heritage and tourism have been connected sever since both concepts were established in the beginning of the 19th century ${ }^{4}$ (Lazarotti 2000). From the moment of the recognition and listing as heritage, the building 'deserves' to be preserved. Simply, because this recognition is the consequence of a cultural construction that made that, at a given time, a site gained a sense for the collectivity, a clear enough and shared meaning justifying its maintenance (Bertho-Lavenier 1998). One can then consider that, amongst others, the interest and gaze of visitors travelling in order to see or visit the building/site 'consecrate' them as heritage. The link between the development of tourist activities due to the increasing mobility and the heritage site listing is thus undeniable. Yet, the relationship has always been conflictual and can be observed at different levels:

1. Official texts: Since their earliest days in the beginning of the 20th century, charters recommendations and conventions aiming at protecting heritage sites have mostly managed to get around aspects connected to tourism (linguistically and contents wise).

2. Many sites - still today - distinguish the management of a site from the preserving of a site and little common management policies are in place leading to use conflicts.

3. Research has either mainly focused on the nature of heritage or the experience of the visitors and their activities on site. Both sides, heritage research and tourism research stick to their preoccupations without trying to integrate the other perspective. There is in fact little evidence in how far both sides perceive their own actions or role when it comes to heritage preservation. Yet, they do all agree that heritage is only useful for tourism if well preserved. They lesser agree on the fact that heritage sites need tourism to be preserved or at least that tourism can contribute to heritage preservation (Diekmann \& Gillot 2010).

The reasons for this dichotomy lie in the fundamental different approach of stakeholders of both sites as well as their various level of responsibilities and implication. The tourist sector covers a wide range of private and public actors from tour operators, coach services and tourist guides to tourism authorities. On the heritage side, while in majority more public stakeholders, the sector is represented by public authorities responsible for heritage preservation and curators, responsible for specific sites. Table 1 represents the opposite perception of the heritage administrator and the tourism stakeholder. While tourism stakeholders see a heritage site as an asset that is to be consumed by tourists (or visitors) with a clearly economic perspective contributing to produce wealth, heritage stakeholders refer to the cultural values of a site and its role for the local/regional or national identity (Diekmann \& Gillot, 2008; Du Cros \& McKercher 2014). For them a heritage site is not to be consumed and has no 'use-value' but needs to be protected (even closed for tourism) in order to preserve the site for the following generations. This perception is very much connected to the inherent definition of heritage that is something we've been handed down and that needs to be passed on for its sole cultural values for a community/nation or even humanity.

In that perspective, tourists (and certainly not sightseeing tourists) are not the target of curators of heritage sites for in a certain way they consider that tourists do not value the heritage for the intrinsic values, but as an asset of consumption.

Tunbridge and Ashworth (1996) explain that 'the exploitation of historic resources for the creation of heritage inevitably affects the nature of those resources, leading to fears that they will be subject to damage, distortion, or just depletion. The relation of heritage to its resources is characterised as at once 'destructive', 'dishonest, parasitical and a form of cultural prostitution'.

3 Although overtourism goes beyond heritage 
Table 1. Difference of perception of stakeholders

\begin{tabular}{lll}
\hline & Tourism STAKEHOLders & Heritage AdMinistrations \\
\hline STRUCTURE & Private and public & Mostly public or trusts \\
PERCEPTION & Asset & Cultural property \\
VAlUES & Economic & Cultural \\
AIMS & $\begin{array}{l}\text { Profit orientated exploitation- } \\
\text { maximising tourism activity }\end{array}$ & $\begin{array}{l}\text { Non-profit orientated conservation- } \\
\text { limiting tourism activity }\end{array}$ \\
TARGET & Tourists & Local or national community \\
GROUPS & & \\
\hline
\end{tabular}

Source: (Diekmann \& Gillot, 2008, p. 265)

Yet, heritage and tourism need each other. Along with the mediatised heritage sites suffering overcrowding, there are many sites that suffer from natural decay as their preservation is not a priority for authorities. Generally, this is the case for sites that are not open to visitors. While tourism income hardly covers preservation expenses, it can at least contribute. Economic impacts (direct and indirect) from tourism activities on - and around sites can be significant if well managed. In many regions, transforming a monument or a site into a heritage attraction, can help to regenerate and preserve a site. The condition however consists in the balance of managing the intrinsic cultural values and the economic values of the sites. This balance can only be achieved if all stakeholders are involved in the management process at large.

In that perspective, UNESCO requires since 2008 (only) a management plan for world heritage sites. According to English Heritage, a management plan aims at

- highlighting the significance of the site

- identifying the organisations and individuals with an interest in the site, including the existing frameworks that can be used to protect it,

- identifying the values of the Site and to set out an agreed overall guiding strategy for the partner organisations,

- addressing issues which are of concern through their individual remits and by working cohesively together

Integrating all above-mentioned issues (protection, VFM, presentation and interpretation) will allow to have a balanced and sustainable approach to site protection and visitor management.

\section{Brussels's 'Grand Place'}

The Grand Place is a world heritage site (listed in 1998) with a management plan since 2012. It is a tourism hotspot in an open public space with multiple function and use values for an important number of public and private stakeholders ranging from residents, shopkeepers to tourists on the user side, and a broad variety of urban authorities on the other side. From a local neighbourhood with a social urban infrastructure and services, the area developed in 50 years into a touristified district with more than 100 souvenir shops currently (see fig. 1).

First drafts of management plans existed since 1995, reviewed 1999 planning tourism activities and events around the Grand Place with the aim of spreading tourism to less visited areas in the centre; concentrate shopping areas on principal roads and the creation of residential areas. These two drafts weren't followed by any action. A new plan in 2007 was confronted with difficulties in managing the commercial areas, the confrontation of heritage management vs development plan by different authorities and a lack of collaboration of owners and residents (Diekmann \& Gillot, 2010). In 2008, a survey with residents highlighted the increasing worries of residents on high prices, parking problems and conflicts of usage around the Grand Place. 
The difficulties were mainly connected to the opposing perception and understanding of the heritage and tourism stakeholders. In the MECOAN project research (see Diekmann \& Gillot, 2010), the persons responsible for the heritage preservation of the Grand Place refused an in-depth interview pretending they were not competent for tourism issues - even related to heritage. They had a very protectionist approach and considered mass tourism as an evil to avoid rather than an activity to control. Without any specific approach to tourism management of heritage sites, they recognised however that education and sensitization could contribute to protect heritage sites. Associations and museum curators showed a more constructive approach to tourism recognising the economic resources but expressed fear of museification of heritage (Diekmann \& Gillot, 2010).

On the other side (tourism), the private sector did not wish to take a position for lack of 'opinion' and time. They explained not feeling competent in heritage matters even though they considered it a major asset. In 2010 they could not see any conflicts but were interested in sustainable tourism management. The tourism authorities wanted in fact to increase the number of tourists in order to create more jobs with the aim of promoting other quarters to achieve a sustainable management of tourist flows.

Figure 1. Development of the commercial sector around the Grand Place
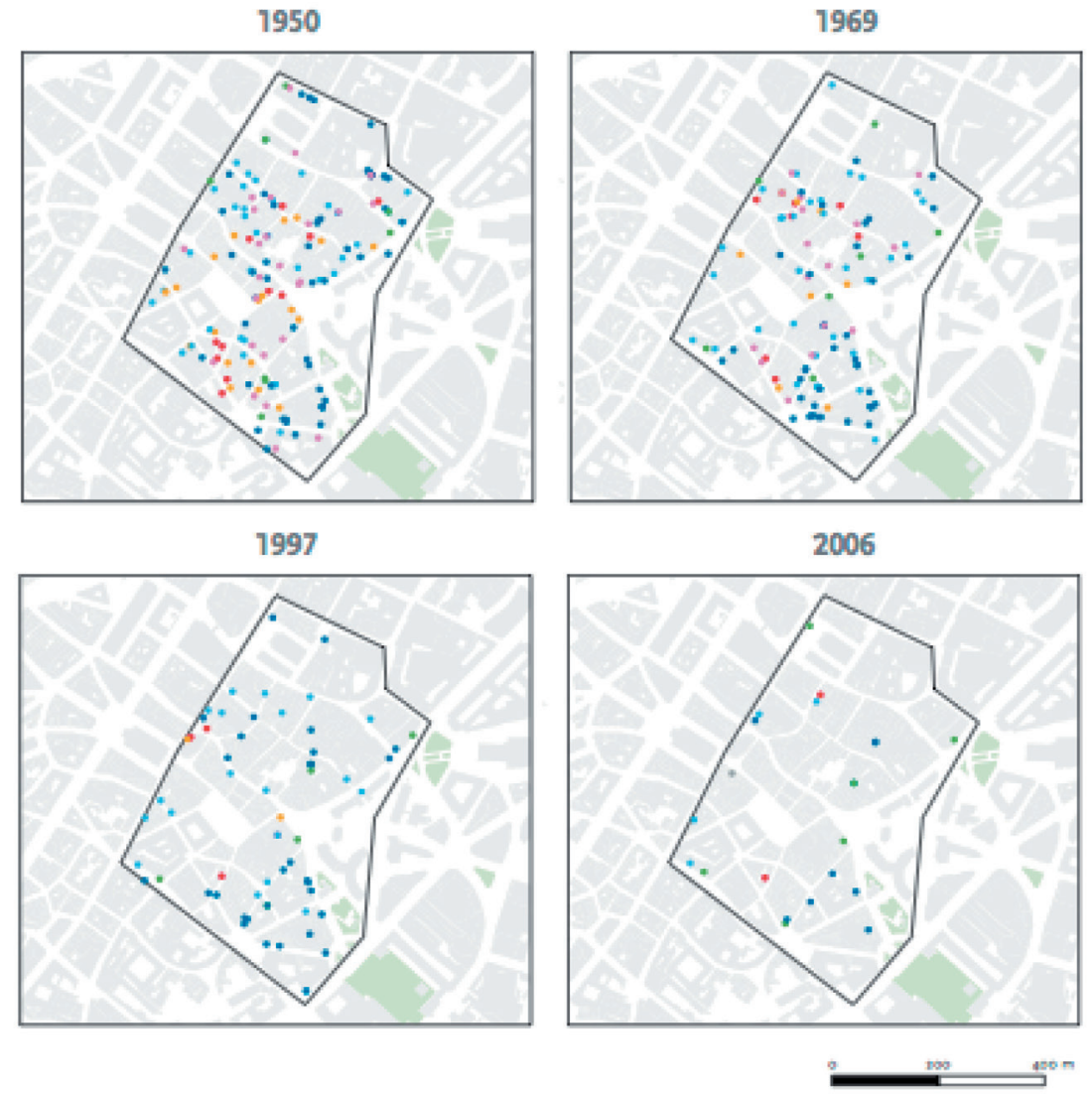

\author{
Alimentution getnerale \\ Algemene voeding \\ Grocery store \\ Boucherie \\ - Slageri. \\ Butcher \\ Boulangerie \\ - Bakkeri] \\ Bakery \\ Coiffeur \\ - Kapper \\ Hairdresser \\ Joumsux 8 livres \\ - Kranten $\&$ boeken - \\ Newspapers \& books \\ Pharmacie \\ Apotheek \\ Pharmacy \\ Superute \\ Supertette \\ Corvenience store
}

Quartier de la Crand.Plac

Wijk van de Grote-Markt

Grand Place district

Espacé wert

Groene fuimite

Green area

Source: (Wayens \& Grimmeau, 2003)

In 2012, eventually a management plan saw the light with actions and projects around 5 strategic goals (mainly urban and heritage authorities) including management of the goods; preservation of heritage which guarantees it as a whole and its authenticity; development of a functional mix, in particular between housing and trade; improving the living environment; raising awareness, promotion, exchange and tourism development and enforcing previously started policies.

However, the area is facing increasing problems, such as the uncontrolled growth of bargain souvenir shops with low cost displays on the main access roads to the Grand Place and the increase of fast-food and snack restaurants targeting group short stay group tours. 
Analysing the latest management plan, it occurs that not all stakeholders are part of the drafting committee as stipulated by the UNESCO guidelines. The heritage management plan for the 'Grand Place' includes various divisions of the urban administration with a focus on heritage administration. Public tourism stakeholders and resident associations are only associated for specific actions of the plan. Private tourism stakeholders are not represented. However, their involvement could help management of visitor flows particularly in peak seasons. While it can be considered as a positive step forwards that public tourism stakeholders are at least associated, the lack of integrated management threatens a sustainable development and might lead in the long run to the feared overtourism. But Brussels is certainly not the sole example for this type of development.

Thank you!

\section{REFERENCES}

Diekmann, A., \& Gillot, L. (2010). Heritage and Tourism: A dialogue of Deaf? The case of Brussels in Rivista di Scienze del Turismo, 2, 263-280.

Du Cros, H., \& McKercher, B. (2014). Cultural tourism. Oxon: Routledge.

Lazzarotti, O. (2000). Patrimoine et tourisme: un couple de la mondialisation. Mappemonde, 57(1), 12-16.

Tunbridge, J. E., \& Ashworth, G. J. (1996). Dissonant heritage: The management of the past as a resource in conflict. Chichester: John Wiley \& Sons.

UNWTO. (2004). Handbook for Congestion Management in Natural and Cultural Sites. Madrid: World Tourism Organisation.

Wayens, B., \& Grimmeau, J. P. (2003). L'influence du tourisme sur la géographie du commerce de détail en Belgique. Belgeo: Revue Belge de Géographie, 3, 289-302. 